\title{
Resource recovery and waste-to-energy from wastewater sludge via thermochemical conversion technologies in support of circular economy: a comprehensive review
}

\author{
Raaj R. Bora', Ruth E. Richardson ${ }^{2,3}$ and Fengqi You ${ }^{1,3^{*}}$ (D)
}

\begin{abstract}
With the rapid rise in global population over the past decades, there has been a corresponding surge in demand for resources such as food and energy. As a consequence, the rate of waste generation and resultant pollution levels have risen drastically. Currently, most organic solid wastes are either land applied or sent to landfills, with the remaining fraction incinerated or anaerobically digested. However, with the current emphasis on the reduction of emissions, nutrient recovery, clean energy production and circular economy, it is important to revisit some of the conventional methods of treating these wastes and tap into their largely unrealized potential in terms of environmental and economic benefits. Wastewater sludge, with its high organic content and fairly constant supply, provides a great opportunity to implement some of these strategies using thermochemical conversion technologies, which are considered as one of the alternatives for upcycling such waste streams. This paper summarizes the results of prominent studies for valorizing wastewater sludge through thermochemical conversion technologies while drawing inferences and identifying relationships between different technical and operating parameters involved. This is followed by sections emphasizing the environmental and economic implications of these technologies, and their corresponding products in context of the broader fields of waste-to-energy, nutrient recycling and the progress towards a circular economy.
\end{abstract}

Keywords: Wastewater sludge, Waste-to-energy, Circular economy, Nutrient recycling, Thermochemical

\section{Background}

Wastewater treatment plants (WWTPs) today have become an integral part of a community's infrastructure that are capable of handling the constantly varying quantities and concentration of wastewater produced daily

\footnotetext{
* Correspondence: fengqi.you@cornell.edu

'Robert Frederick Smith School of Chemical and Biomolecular Engineering, Cornell University, Ithaca, NY 14853, USA

${ }^{3}$ Atkinson Center for a Sustainable Future, Cornell University, Ithaca, NY 14853, USA

Full list of author information is available at the end of the article
}

[1]. Over the years, while certain modifications and upgrades of WWTPs have been made periodically to the existing infrastructure, the underlying design and principles remain almost the same [2]. However, recent developments and trends, such as the rapidly growing human population, increased consumption of resources and a consequential rise in waste and pollutant levels, have led certain groups to believe that the renovation of the original design is essential [3]. While WWTPs are predominantly looked at as facilities where contaminated water is treated to produce clean water and a semi-solid

(c) The Author(s). 2020 Open Access This article is licensed under a Creative Commons Attribution 4.0 International License, which permits use, sharing, adaptation, distribution and reproduction in any medium or format, as long as you give appropriate credit to the original author(s) and the source, provide a link to the Creative Commons licence, and indicate if changes were made. The images or other third party material in this article are included in the article's Creative Commons licence, unless indicated otherwise in a credit line to the material. If material is not included in the article's Creative Commons licence and your intended use is not permitted by statutory regulation or exceeds the permitted use, you will need to obtain permission directly from the copyright holder. To view a copy of this licence, visit http://creativecommons.org/licenses/by/4.0/. The Creative Commons Public Domain Dedication waiver (http://creativecommons.org/publicdomain/zero/1.0/) applies to the data made available in this article, unless otherwise stated in a credit line to the data. 
byproduct (sludge), they also possess high potential in terms of resource recovery [4]. This has consequently led to the renaming of certain WWTPs as water resource recovery facilities [5].

One of the key components for maximizing resource recovery in a WWTP is the wastewater sludge that is produced through the primary and secondary treatment stages, as well as the anaerobic digester (AD), if present. Not only is the sludge rich in organic contents with valuable nutrients including nitrogen $(\mathrm{N})$ and phosphorus (P), but it also has considerable energy embedded within it (higher heating value (HHV) of 15-20 MJ/ $\mathrm{kg}$ dry sludge), thus becoming an optimal stream for implementing waste-to-energy and nutrient recycling strategies [1, 2]. However, only some of the current wastewater sludge disposal methods are designed to recover resources (and even if they are, the recovery parameters are very difficult to control). In 2015, approximately $55 \%$ of the 7.2 million dry tons of wastewater sludge produced in the United States was land applied, while landfilling (30\%) and incineration (15\%) accounted for the majority of the remaining shares [1]. Although some of these conventional methods facilitate partial nutrient and energy recovery, (Fig. 1), they are unable to utilize the potential of the sludge to the fullest
[2]. Additionally, the presence of harmful substances such as pathogens, hormones, antibiotics, heavy metals, and persistent organic pollutants in the sludge acts as a further deterrent against the continued employment of some of the current disposal methods [6-10]. The utilization of the sludge in the construction industry is another established pathway with specific applications including co-combustion as a kiln fuel, in cement kilns for mortar production as well as stabilization by combining with wet cement [11-14]. These pathways provide an additional economic benefit while disposing the sewage sludge unlike some of the other conventional methods. However, the presence of heavy metals and additional laws prove to be a restriction to the maximum economic value that can be obtained from the sludge through these methods [11].

Thermochemical technologies, on the other hand, facilitate the conversion of certain feedstocks into useful and highly-valued products at relatively high pressure and temperature (with varying amount of oxygen requirements). Recently, a growing number of studies on thermochemical conversion of sewage sludge have been reported [15-17]. Sludge management and treatment is a capital-intensive process that accounts for up to 50\% of the total cost of wastewater treatment $[18,19]$, and

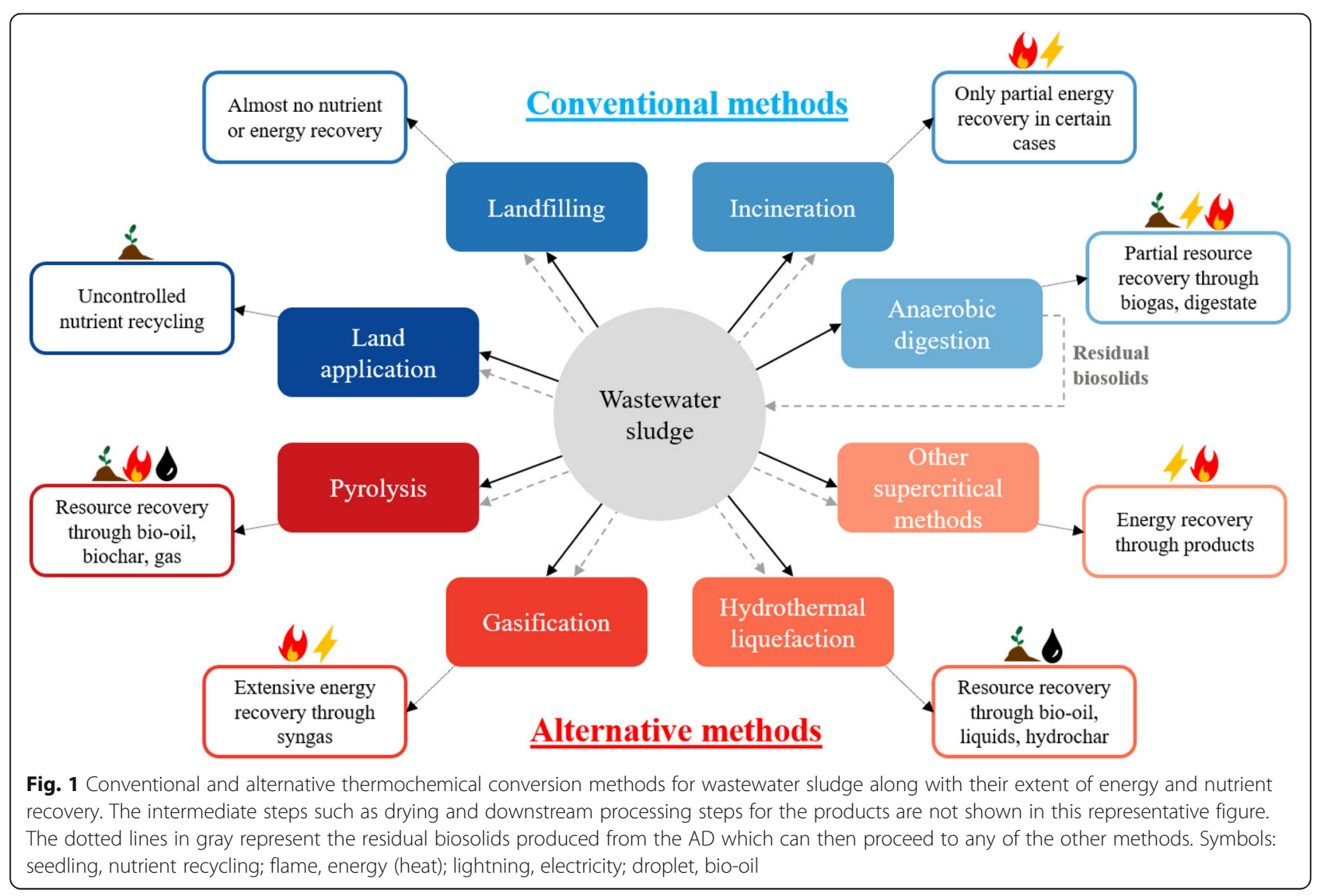


contributes approximately $40 \%$ of total greenhouse gas (GHG) emissions associated with the WWTP [20]. Existing review papers have looked at different aspects of these processes, but an up-to-date review comparing all the thermochemical technologies for treating wastewater sludge together with insights into broader fields such as circular economy and nutrient recycling is currently missing $[2,17,21,22]$.

The objective of this paper is to present an overview of thermochemical technologies including pyrolysis, gasification, hydrothermal liquefaction (HTL), along with a brief summary of other hydrothermal technologies such as supercritical water gasification (SCWG) and supercritical water oxidation (SCWO), for wastewater sludge treatment. The basic principles and parameters are discussed along with accompanying statistics derived from a comprehensive literature review with an emphasis on their potentials for resource recovery. This is followed by an extensive discussion on the application and feasibility of these processes with respect to energy and nutrient recovery, environmental impacts and economic considerations.

\section{Main text}

\section{Current treatment methods}

This section provides a brief overview of the current handling and disposal methods used for wastewater sludge, such as land application, landfilling, incineration and anaerobic digestion (AD) (Fig. 1). While AD has been included in the comparison here, it is important to note that ADs already exist within many of the larger WWTPs as a sludge stabilization step [23]. The residual biosolids (or digested sludge) produced from the ADs can also be a potential feed to any of the other technologies as portrayed in Fig. 1. However, some of the thermochemical technologies (especially hydrothermal technologies) have the potential to treat dewatered, undigested sludge too and they would then act as alternatives to ADs especially for sludge from smaller WWTPs without an existing AD [24]. A detailed review and analysis of the prominent thermochemical technologies, including pyrolysis, gasification and HTL, is presented later. Figure 1 summarizes all of the technologies considered along with their main products and environmental and economic benefits.

\section{Land application}

Land application has been one of the most prominent methods of disposing wastewater sludge over the years with over 40 and $55 \%$ of the total municipal wastewater sludge generated in the European Union and United States being applied on agricultural land, respectively $[11,25]$. This has been a popular choice as it is inexpensive, does not require any specialized equipment (only vehicles to first transport and then spread the sludge on the fields) and has the potential to recycle valuable nutrients back to the soil. However, the ratio of the nutrients cannot always be maintained, thus leading to eutrophication and over-fertilization. Additionally, over the past few decades there have been rising concerns regarding the presence of harmful substances such as pathogens, heavy metals and polycyclic aromatic hydrocarbons (PAH) at different concentrations in the landapplied sludge $[7,8,26,27]$. This has led to some stringent environmental laws, with the most prominent being the Environmental Protection Agency's (EPA) Part 503 rule to require treatment of wastewater sludge (that is to be land applied) and subsequent categorization into class A and B biosolids depending on certain criteria, such as pathogen levels, heavy metal concentration and attraction to vectors $[28,29]$. Furthermore, the possibility of the bioaccumulation of certain antibiotics and endocrine disruptors followed by their introduction into the food chain through land applied biosolids has led to society looking for different options to safely tackle the wastes [30]. Zhang et al. [31] suggest that one way in which sludge could still be land applied would be to fertilize energy crops instead of the traditional food crops. However, it is uncertain if all problems with the method could be avoided through this move.

\section{Landfilling}

Landfilling is another method that has commonly been used for wastewater sludge disposal. The advantage that it provides is that the sludge (or biosolids) remains covered and hence the spread of pathogens and corresponding attraction of vectors can be controlled to an extent [2]. However, leaching through the landfill is not entirely avoidable, and this poses a threat of contamination to the groundwater below [31]. Fugitive methane emissions to the atmosphere from the landfills are also a cause for concern due to the high global warming potential of methane [32]. Furthermore, by landfilling rich organic streams such as wastewater sludge, the opportunity to recover valuable nutrients, which are otherwise only available through energy intensive fertilizers, is lost. Lastly, with the decreasing availability and increasing prices of land globally, landfills are becoming more expensive to manage in a world where the concept of circular economy is rapidly gaining attention [30].

\section{Incineration}

Incineration of wastewater sludge is a conventionally used method with its biggest advantage being the reduction in the volume by up to $70 \%$ as well as the destruction of pathogens and toxic organic compounds owing to the high operating temperatures [33]. Furthermore, it leads to odor reduction and minimal utilization of land 
as compared to some of the other conventional methods such as landfilling [11]. However, the remaining ash often contains toxic elements and has to be disposed in a landfill subsequently. Additionally, stringent regulations regarding the concentration of air pollutants released into the environment make incineration an expensive choice owing to the extensive gas cleaning equipment required $[19,30]$. Some other deterrents to the installation of incinerators are the negative public perception surrounding it, as well as the energy requirements for drying the sewage sludge before incineration [33].

\section{Anaerobic digestion}

$\mathrm{AD}$ is a biological method that consists of multiple consecutive steps (hydrolysis, acidogenesis, acetogenesis and methanogenesis) to break down the organic feed into an energy rich gas stream (biogas) and a nutrient rich slurry termed as digestate or residual biosolids [31]. The biogas is often used for energy production (heat and/or electricity) to utilize within the WWTP itself [19]. Additionally, the $\mathrm{AD}$ is also used to stabilize the sludge. However, the process is comparatively slow as the sludge needs to be retained for a number of days (approximately 10-20) [34]. Moreover, the process and its products are dependent and sometimes sensitive to the properties of the feed as well as the operating conditions, because the microorganisms need optimal temperatures and $\mathrm{pHs}$ to function efficiently. Even at optimal conditions though, only a fraction of the organic matter is converted into biogas, while the rest finds its way into the digestate along with other nutrients and toxic substances which are not destroyed at the bioreactor temperature [2]. While AD has been included as a technology to compare the thermochemical technologies with, there is a high likelihood of coupled systems in the future such as the treatment of the residual biosolids produced from existing ADs through thermochemical technologies. This is supported by the fact that the coupling could improve energy recovery and also because a large fraction of the wastewater sludge (based on mass) produced in countries such as the United States is already digested in existing WWTPs [23, 35].

\section{Thermochemical treatment methods}

A wide range of thermochemical conversion technologies, such as pyrolysis, gasification, HTL, SCWG, and SCWO, have been reported for wastewater sludge treatment $[2,21,31]$. For pyrolysis and gasification processes, sludge has to be dewatered or dried in advance; whereas it can be treated directly with the hydrothermal methods, such as HTL, SCWG and SCWO [24, 36]. While some studies also specify whether the sludge is digested (residual biosolids), this practice is not followed in all papers and the feed is often simply referred to as wastewater sludge. Thus, it is important to note that the wastewater sludge in some of the experiments could represent primary and secondary sludges (with or without dewatering), whereas others consider digested sludge from an existing AD in a WWTP. In terms of energy recovery, pyrolysis and HTL are able to convert organic compounds into liquid bio-oil, while gasification and SCWG focus on the production of syngas. By contrast, $\mathrm{SCWO}$ is not able to produce any forms of biofuels. The downstream processing of the products from these technologies plays a key role in determining the feasibility of these technologies, too. As seen from Fig. 2, there are multiple steps involved in the production, separation and processing of the products before they can be utilized or sold as sources of revenue.

\section{Overview of existing studies}

Multiple studies for each thermochemical technology to specifically treat and valorize wastewater sludge were reviewed. While most of the selected studies were dedicated experiments with different goals, locations, parameters, technologies and performance metrics, a few of them also involved a review of multiple experiments that had been performed in the past in order to provide a comparison. All the studies with available basic data, including feed type, technology type and product distribution, were analyzed; only those which lacked more than one of these details were excluded from the literature analysis, though some of them are mentioned in the later discussions.

\section{Input wastewater sludge characteristics}

The limit on input moisture content for the thermochemical conversion technologies varies considerably and that can have an effect on the overall environmental and economic feasibility of the technology. Sludge drying and pre-treatment of sludge are very energy intensive [16]. While certain hydrothermal technologies are capable of handling input sludge with moisture concentration of over $80 \%(\mathrm{w} / \mathrm{w})$ as shown in Fig. 3, other technologies such as pyrolysis and gasification require considerable drying of the feed sludge down to concentrations of $0-20 \%(\mathrm{w} / \mathrm{w})$ most commonly. When analyzing various papers for the input moisture content, it was found that most authors reported either the moisture content of the initial sludge obtained (mi) or the moisture content of the sludge that was fed into the reactor (mf). Only a handful of studies provided both values to enable the calculation of the energy for the drying required $[37,38]$. Additionally, while we have provided the moisture content of the different feeds, the proximate (Table 1, Fig. 4) and ultimate analysis (Table 2, Fig. 5) provide values of the feed composition on a dry basis 


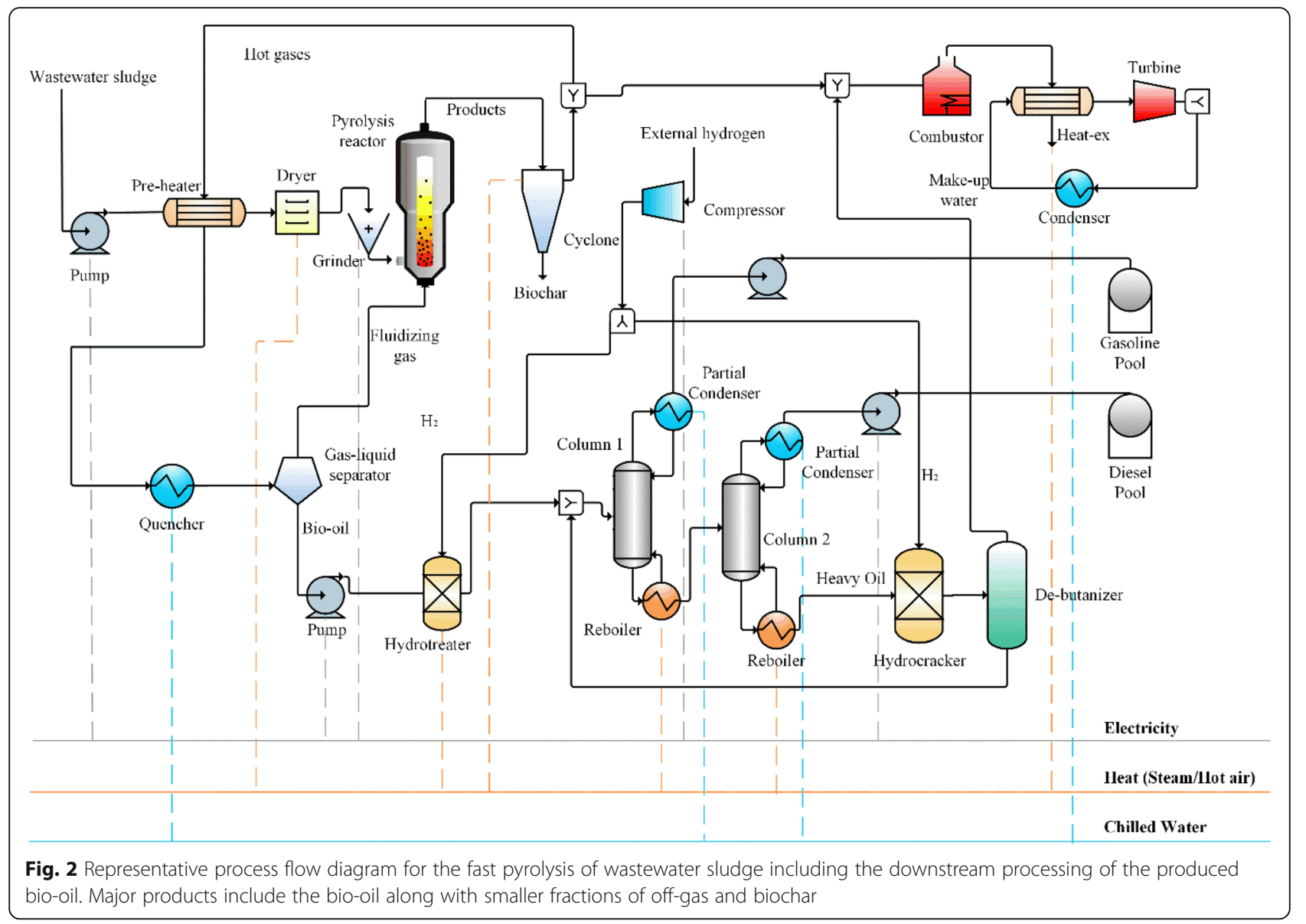

and dry ash free basis (dab), respectively. Hence, these values can be used to determine the dry basis composition of the feed.

Based on the proximate analysis (Table 1, Fig. 4) and ultimate analysis (Table 2, Fig. 5), it can be observed that the composition of the wastewater sludge across different studies was fairly uniform with some variations in the volatile matter and $\mathrm{C}$ concentration. This is important to note as the feed composition has a direct impact on the quality as well as distribution of products. The volatile matter is eventually converted into the gaseous and liquid fuels whereas the $\mathrm{C}$ concentration and distribution determines the energy content of the products. Higher ash content is generally unfavorable as it leads to a lower energy conversion efficiency, and could lead to problems in the equipment too. The elemental

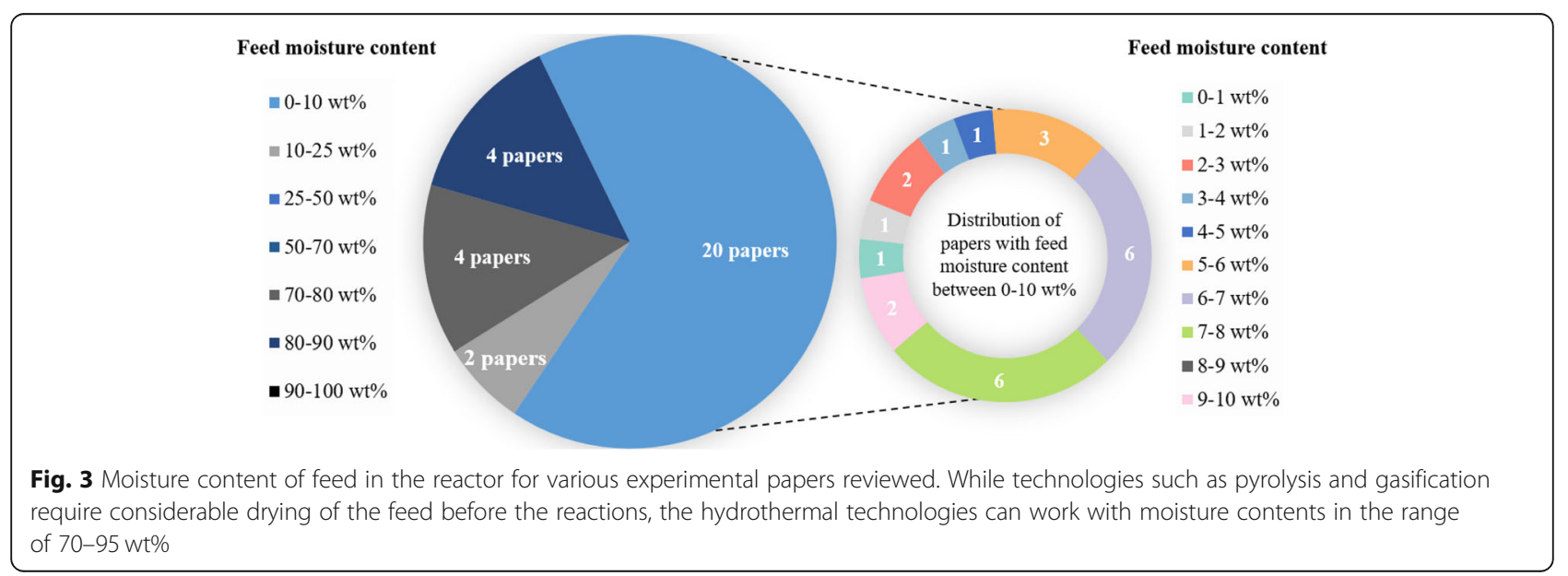


Table 1 Proximate analysis of WW sludges reported in the experimental papers reviewed in this study. The values are converted into wt\% on a dry basis

\begin{tabular}{|c|c|c|c|c|c|}
\hline Study No. & Study & Feed moisture input (mf) \% & Ash & Fixed Carbon & Volatile Matte \\
\hline 1 & Trinh et al. [39] & 7.30 & 50.49 & 8.52 & 40.99 \\
\hline 2 & Fonts et al. [40] & 6.60 & 44.22 & 6.42 & 49.36 \\
\hline 3 & Shen et al. [41] & 3.00 & 22.60 & 16.10 & 61.30 \\
\hline 4 & Alvarez et al. [42] & 5.60 & 37.20 & 8.60 & 54.20 \\
\hline 5 & Chen et al. [43] & 6.58 & 43.44 & 5.84 & 50.72 \\
\hline 6 & Chen et al. [44] & 84.00 & 28.96 & 9.41 & 61.63 \\
\hline 7 & Freda et al. [45] & 3.53 & 30.73 & 2.67 & 66.59 \\
\hline 8 & Lee et al. [46] & 6.33 & 27.94 & 8.32 & 63.75 \\
\hline $9 a$ & Fonts et al. [47] & 6.70 & 42.77 & 6.86 & 50.38 \\
\hline $9 b$ & & 5.30 & 54.91 & 4.65 & 40.44 \\
\hline $9 c$ & & 7.10 & 44.13 & 5.71 & 50.16 \\
\hline 10 & Huang et al. [48] & 11.79 & 27.89 & 10.00 & 62.11 \\
\hline 11 & Xie et al. [49] & 4.53 & 15.01 & 16.42 & 68.57 \\
\hline 12 & Zhou et al. [50] & - & 17.50 & 0.30 & 82.20 \\
\hline 13 & Calvo et al. [51] & 7.90 & 37.90 & 7.10 & 55.10 \\
\hline 14 & Qian et al. [52] & 87.00 & 27.00 & 21.90 & 51.12 \\
\hline 15 & Pedroza et al. [53] & 6.00 & 40.53 & 2.13 & 57.34 \\
\hline
\end{tabular}

concentration of $\mathrm{N}$ (Table 2) is considerably high as compared to other organic waste streams such as woody biomass and food waste and this stresses the need for nutrient recycling applied to the sludge.

\section{Pyrolysis}

Pyrolysis involves the thermal decomposition of the feed in anaerobic or very limited oxygen environments [55]. The products of the pyrolysis process include a liquid- phase bio-oil, a solid product termed "biochar", and a gaseous stream $[56,57]$. One of the advantages of pyrolysis is that the product distribution can be optimized based on the operating conditions, such as temperature and residence time. Thus, while moderate temperatures (around $500^{\circ} \mathrm{C}$ ) and very short reaction times (in the order of milliseconds to seconds) favor bio-oil production through fast pyrolysis, lower heating rates (with a temperature of 400 $600{ }^{\circ} \mathrm{C}$ and a residence time of minutes to hours) support

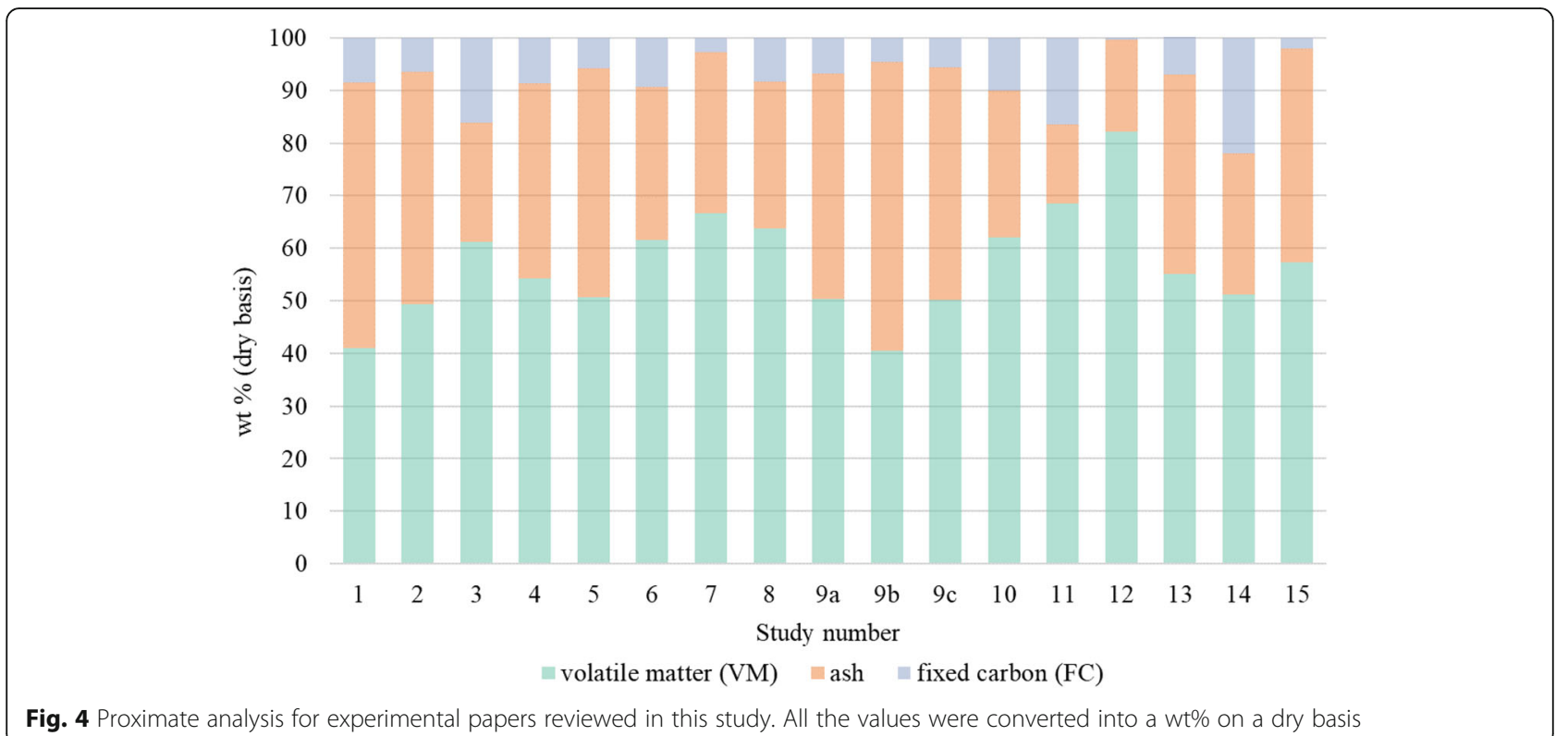


Table 2 Ultimate analysis of experimental papers reviewed in this study. The values are converted into wt\% on a dry ash free (daf) basis

\begin{tabular}{lllllll}
\hline Study No. & Study & C & O & N & S & H \\
\hline 1 & Trinh et al. [39] & 60.09 & 22.10 & 8.58 & 1.93 & 7.30 \\
2 & Fonts et al. [40] & 47.19 & 37.31 & 6.64 & 1.36 & 7.50 \\
3 & Shen et al. [41] & 41.78 & 47.38 & 4.30 & 1.14 & 5.40 \\
4 & Alvarez et al. [42] & 40.64 & 41.24 & 7.71 & 3.30 & 7.11 \\
5 & Chen et al. [43] & 52.29 & 29.13 & 7.65 & 2.50 & 8.44 \\
6 & Chen et al. [44] & 53.74 & 33.42 & 6.57 & 1.48 & 4.79 \\
7 & Freda et al. [45] & 58.56 & 29.45 & 4.56 & 0.00 & 7.42 \\
8 & Lee et al. [46] & 48.43 & 34.02 & 8.59 & 0.70 & 8.26 \\
$9 a$ & Fonts et al. [47] & 47.42 & 37.27 & 6.82 & 1.33 & 7.15 \\
$9 b$ & & 48.13 & 36.88 & 6.67 & 1.88 & 6.46 \\
$9 \mathrm{c}$ & & 47.19 & 37.31 & 6.64 & 1.36 & 7.50 \\
10 & Huang et al. [48] & 51.58 & 31.41 & 8.78 & 0.00 & 8.22 \\
11 & Xie et al. [49] & 53.21 & 33.28 & 6.12 & 0.00 & 7.39 \\
12 & Zhou et al. [50] & 52.61 & 32.06 & 6.86 & 0.00 & 8.47 \\
13 & Calvo et al. [51] & 58.29 & 23.67 & 9.02 & 1.77 & 7.25 \\
14 & Qian et al. [52] & 51.51 & 33.48 & 7.84 & 1.15 & 6.03 \\
15 & Xu et al. [54] & 52.48 & 25.58 & 9.01 & 4.96 & 7.97 \\
\hline & & & & & &
\end{tabular}

the optimized production of the solid biochar through slow pyrolysis $[22,58]$.

The role of the operating temperature in the pyrolysis processes has always been vital as that ultimately determines the distribution and potential for energy recovery from the products. Thus, many of the reviewed studies investigated the optimal temperature range for pyrolyzing wastewater sludge (Table 3). Trinh et al. [39] looked at the effects of reaction temperature (increasing from $475^{\circ} \mathrm{C}$ to $625^{\circ} \mathrm{C}$ ) on the fast pyrolysis product distribution, and specifically the bio-oil properties. They identified $575^{\circ} \mathrm{C}$ as the optimum temperature for bio-oil production (yield of $41 \mathrm{wt} \%$ daf) and found that increasing temperatures led to a decrease in biochar yield and an increase in gas yield. Shen et al. [41] studied the effects of changing temperature $\left(300^{\circ} \mathrm{C}\right.$ to $\left.600^{\circ} \mathrm{C}\right)$ and gas residence time ( 1.5 to $3.5 \mathrm{~s}$ ) on the product distribution and obtained a maximum oil yield ( $30 \mathrm{wt} \%$ daf of feed) at $525^{\circ} \mathrm{C}$ and a residence time of $1.5 \mathrm{~s}$. Certain studies were conducted in the presence of catalysts to further enhance the recovery of products. Xie et al. [49] conducted catalytic pyrolysis (zeolite catalyst) of wastewater sludge in a microwave oven. An optimum temperature for bio-oil production (24.4 daf wt\%) was determined at $550{ }^{\circ} \mathrm{C}$. The biochar yield decreased while the gas yield increased with the increase in the temperature of the reactor. Most of the studies had a similar explanation for the trends in the bio-oil yield with respect to temperature. On moving higher than the optimum yield temperature, it is found that secondary decomposition reactions are initialized which break the oil down into lighter gaseous compounds $[39,41]$.

Since the drying stage for pyrolysis is extremely energy intensive, certain groups experimented with the utilization of microwave reactors to improve the net energy balances. Huang et al. [48] carried out the microwave assisted pyrolysis of wastewater sludge in combination with rice straw to tackle the high moisture content and to improve the efficiency of microwave heating. Zhou et al. [50] utilized a continuous fast microwave pyrolysis system and obtained optimal bio-oil

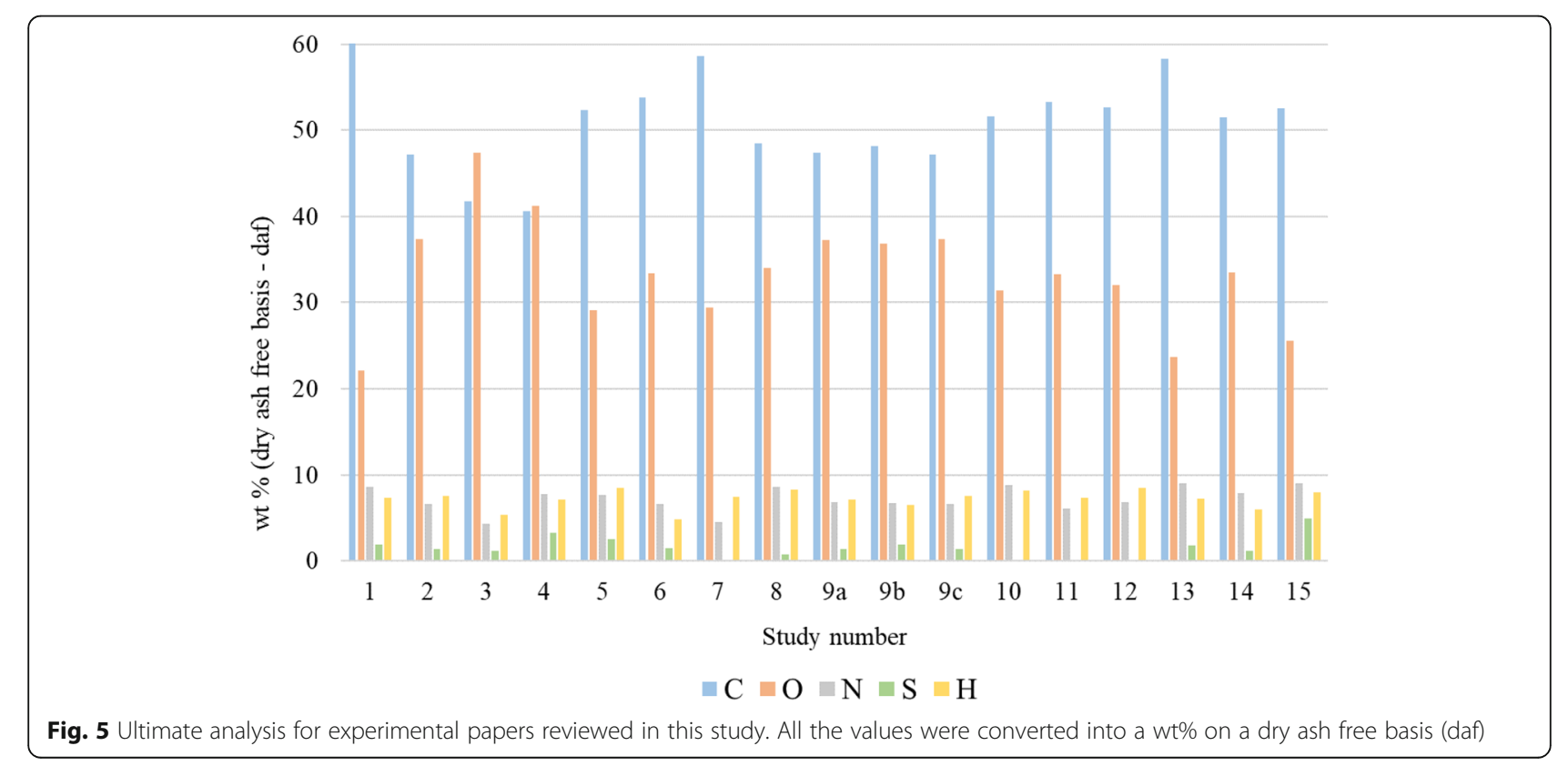


Table 3 Operating parameters and product distribution of pyrolysis papers that were reviewed. Only experimental papers which provided at least two of the table's parameters are presented here

\begin{tabular}{|c|c|c|c|c|c|c|}
\hline Study & $\begin{array}{l}\text { Feed moisture } \\
\text { content (wt\%) }\end{array}$ & Reactor type & $\begin{array}{l}\text { Operating } \\
\text { temp }\left({ }^{\circ} \mathrm{C}\right)\end{array}$ & $\begin{array}{l}\text { Gas yield } \\
\text { (wt\%) }\end{array}$ & $\begin{array}{l}\text { Bio-oil yield } \\
(w t \%)\end{array}$ & $\begin{array}{l}\text { Solid yield } \\
\text { (wt\%) }\end{array}$ \\
\hline Trinh et al. [39] & 7.3 & Centrifuge & $425-625$ & $13-19$ & $26-54$ & $22-55$ \\
\hline Fonts et al. [59] & 6.6 & Fluidized bed & $250-500$ & 31.7 & 49.2 & 19.7 \\
\hline Alvarez et al. [42] & 5.6 & Conical spouted bed & $450-600$ & & $45.4-48.5$ & \\
\hline Shen et al. [41] & 3 & Fluidized bed & $300-600$ & & 30 & \\
\hline Huang et al. [48] & 11.79 & Microwave & - & & 25.5 & \\
\hline Xie et al. [49] & 4.53 & Microwave oven & $450-600$ & & 20.9 & \\
\hline Zhou et al. [50] & - & Continuous fast microwave & $450-600$ & $11-25$ & $16.47-39$ & $32.98-62.26$ \\
\hline Pedroza et al. [53] & 6 & Rotating cylinder & $500-600$ & $16-23.3$ & $8-10.5$ & $52.7-61.9$ \\
\hline \multirow[t]{3}{*}{ Fonts et al. [47] } & 6.7 & Fluidized bed & 530 & 25 & 50 & 25 \\
\hline & 5.3 & & 530 & 37 & 46 & 17 \\
\hline & 7.1 & & 530 & 27 & 51 & 22 \\
\hline Park et al. [60] & - & Fluidized bed & $450-470$ & $6.5-10.3$ & $43.5-52.1$ & $39.7-48.7$ \\
\hline
\end{tabular}

yield (41.39 wt\%) at $550{ }^{\circ} \mathrm{C}$. However, they observed that the highest overall energy was obtained at $500^{\circ} \mathrm{C}$ as the gas had energy content of $22.5 \mathrm{MJ} / \mathrm{Nm}^{3}$ which the authors attributed to the absence of a carrier gas as a result of using a microwave based system. Pedroza et al. [53] utilized a rotating cylinder reactor to conduct the fast pyrolysis of dried wastewater sludge and observed a very high solid product concentration (> 50 wt\%).

A majority of the studies reviewed here concentrated on maximizing the recovery of bio-oil owing to its potential economic value. Furthermore, the bio-oils produced from thermochemical technologies such as fast pyrolysis and hydrothermal liquefaction are expected to play a key role in the transition away from fossil-based fuels, especially in the transportation sector as the biooils provide one of the few carbon neutral alternatives for this purpose [61]. However, there are certain limitations associated with the physical and chemical properties of these oils, which prevent them in most cases from being used as drop-in fuels (or a direct substitute for conventional fossil fuels without pretreatment). Fast pyrolysis liquids, in particular, are found to be very viscous and acidic along with the presence of some solids and considerably high water content which affects their utilization as a fuel [62]. These unfavorable properties of the produced oils demonstrate the importance of downstream processing options for various products, as merely obtaining a product would not always guarantee an instant source of energy or revenue.

\section{Gasification}

Gasification involves the partial oxidation of the feed at much higher temperatures than pyrolysis (over $700^{\circ} \mathrm{C}$ ) to produce a gas (termed as syngas) that is rich in carbon monoxide $(\mathrm{CO})$ and hydrogen $\left(\mathrm{H}_{2}\right)$ along with some methane $\left(\mathrm{CH}_{4}\right)$ and carbon dioxide $\left(\mathrm{CO}_{2}\right)$ [63-65]. It is often classified based on the type of gasifying agent, such as air, steam and steam-oxygen [66]. The commonly used reactor types for this technology include fixed bed gasifiers, fluidized bed gasifiers and entrained flow gasifiers [63]. The produced syngas has the potential to be used in multiple applications, such as a combined heat and power (CHP) generation, production of hydrogen gas (through water-gas shift reaction followed by pressure swing adsorption) and conversion into liquid fuels through the Fischer-Tropsch (FT) synthesis [67-69]. There have been some prominent studies by government labs such as National Renewable Energy Laboratory (NREL) which include extensive experimentation as well as the development of detailed process structures for gasification of biomass to obtain useful products such as bioethanol [70-72]. Studies like these form the basis for further investigation of the gasification of different types of organic feeds such as wastewater sludge.

The observed number of studies for the gasification of wastewater sludge were comparatively fewer than the corresponding pyrolysis studies, and the primary objective of most of those studies was to improve the recovery of hydrogen in the syngas using various gasifying media. Lee et al. [46] utilized steam to gasify wastewater sludge with an emphasis on the kinetics as well as improving hydrogen yield. Hydrogen-rich (43-46 vol\%) gas was successfully obtained through the corresponding experiments at $1000{ }^{\circ} \mathrm{C}$. A few other studies involving steam gasification conducted by $\mathrm{Hu}$ et al. [73] and $\mathrm{Li}$ et al. [74] led to syngas with slightly lower hydrogen concentrations $\left(26 \mathrm{vol} \%\right.$ and $38 \mathrm{vol} \%$, respectively at $\left.800{ }^{\circ} \mathrm{C}\right)$. However, in both cases, it was found that the yield could be improved by increasing the reaction temperature to $1000{ }^{\circ} \mathrm{C}$ or higher. Chen et al. [43] also carried out the 
steam gasification of sewage sludge with the utilization of $\mathrm{CaO}$ as an absorber of the $\mathrm{CO}_{2}$ from the product stream in order to increase the hydrogen concentration and obtained concentrations of $72.8 \mathrm{vol} \%$ to 82.9 at $650^{\circ} \mathrm{C}$.

Freda et al. [45] conducted air-gasification experiments in a continuous bench scale rotary kiln and observed the effects of varying the temperature and equivalence ratio (ER) on the gas yield. They also analyzed the char and found its composition to be dominated by ash (70 wt\%). Commonly reported problems in the gasification experiments included tar formation and high $\mathrm{N}_{2}$ concentrations in the syngas $[75,76]$. Though air gasification is significantly cheaper than using a pure oxygen stream, the syngas produced in the former has high concentrations of nitrogen, as Calvo et al. [51] observed through their experiments ( $\mathrm{N}$ concentration of 34.1-36 vol\%). Thus, the gasification of wastewater sludge can lead to high gas yields, but its composition has to be carefully controlled to optimize energy recovery through downstream processing options, such as combined heat and power recovery and Fischer Tropsch (FT) synthesis to produce liquid fuels.

\section{Hydrothermal technologies}

Hydrothermal technologies are broadly defined as chemical and physical transformations in high-temperature $\left(200-600^{\circ} \mathrm{C}\right)$, high-pressure $(5-40 \mathrm{MPa})$ liquid or supercritical water [77]. Their main advantage is that they can operate efficiently at low solid concentrations of $5-30 \%$ [78]. Very few studies based on HTL have been considered for treating wastewater sludge presumably due to the technology maturity compared to other thermochemical technologies [79]. A comprehensive analysis by $\mathrm{Xu}$ et al. [54] studied the effects of increasing temperatures on the product distribution and characteristics for the hydrothermal liquefaction of sewage sludge. They identified a reaction temperature of $340^{\circ} \mathrm{C}$ as optimal for maximizing bio-oil yield, and also discovered that the overall rise in temperature improved the bio-oil quality, while decreasing solid yield simultaneously. The gas composition was largely dominated by $\mathrm{CO}_{2}(90 \%)$, thus rendering it inappropriate for further energy recovery. Certain studies recognized the potential of the HTL to be able to treat very dilute streams and thus performed experiments for not only digested sludge but also primary and secondary sludge to compare the corresponding product yields [36]. A report published by Snowden Swan et al. [24] evaluated the techno-economic feasibility of replacing current sludge treatment and stabilization methods (specifically ADs) with hydrothermal liquefaction and found promising results as long as the bio-oil could be upgraded and sold profitably.

\section{Other thermochemical technologies}

Apart from the three prominent thermochemical technologies discussed in the preceding sections, there are some others, such as SCWG and SCWO, which are also gaining popularity for the treatment of wastewater sludge. One of the primary reasons behind this is that they can eliminate the energy intensive step of drying the feedstock, similar to HTL [80]. In SCWG, the products are similar to those from regular gasification, with the produced syngas capable of being used as a gaseous fuel or undergoing further processing (such as FT synthesis) to be converted into liquid fuels [81]. There are three predominant categories in which SCWG can be divided according to Peterson et al [77] The first one takes place at high temperatures (greater than $500{ }^{\circ} \mathrm{C}$ ) to produce a hydrogen-rich gas; the second one utilizes catalysts at temperatures between the critical temperature of water $\left(374{ }^{\circ} \mathrm{C}, 22.1 \mathrm{MPa}\right)$ and $500{ }^{\circ} \mathrm{C}$ to produce methane-rich gas; the third category operates at subcritical temperatures with the aid of catalysts to produce a mixed gaseous product [77, 81]. Chen et al. [44] worked on the SCWG system in a fluidized bed reactor and identified factors affecting the gas yield and distribution of components. It was found that increasing temperature as well as decreasing feedstock concentration improved the system's performance. They also showed that adding catalysts such as $\mathrm{K}_{2} \mathrm{CO}_{3}$ enhanced the hydrogen formation. Qian et al. [52] investigated the combined effects of supercritical water gasification (SCWG) and supercritical water oxidation (SCWO) for treating wastewater sludge. As the popularity of hydrothermal technologies increases, it is expected that many more studies investigating their application with respect to wastewater sludge will soon be conducted, and this could lead to better resource recovery and improved economic performance through their utilization.

\section{Feasibility of thermochemical treatment methods for wastewater sludge}

In addition to reviewing the technical parameters and product distribution of the thermochemical technologies, it is also important to study them from the perspective of their applications in broader fields, such as wasteto-energy, water-energy-food nexus, nutrient recycling and circular economy [82-84]. These applications help in differentiating thermochemical technologies from some of the conventional treatment methods and could play a key role in determining the scale at which these technologies are ultimately implemented.

\section{Applications in the waste-to-energy context}

Wastewater sludge has considerable amount of energy embedded within it. As observed from the preceding section, a large fraction of that energy can be recovered 
through the multiple product streams [85]. The energy requirement in the drying phase of a wet feedstock such as wastewater sludge (Fig. 3) is recognized to be a key step in the ultimate energy balances for thermochemical conversion technologies, and emphasizes the need for heat recovery both through output streams and the reactor itself. With hydrothermal technologies, on the other hand, this step is avoided, although the energy requirements for operating the reactor and the additional product separation steps are comparatively higher. Thus, the feed composition from different sources can have an impact on which technology is appropriate for that particular case. Additionally, as discussed in the previous sections, certain feed characteristics such as high ash content could limit the energy recovery through the thermochemical technologies. If that is the case, then other alternative methods such as utilization of the sludge as construction materials could be viable options [11]. The downstream processing of the products also plays an important role, because some methods such as hydrotreating and gas cleaning require considerable amounts of energy along with catalysts or other materials which may be energy intensive to produce [86, 87]. On the other hand, the avoided use of conventionally produced fertilizers, petroleum products, electricity and heat through the substitution with the products derived from thermochemical technologies could help save a massive amount of energy and help water resource recovery facilities achieve their sustainability goals by making them self-sufficient, or even net-exporters of energy [88]. Hence, it is very important to determine the system boundaries for analyzing the net energy through these thermochemical processes, as different boundaries could provide completely different answers [89]. A cradle-tograve life cycle assessment (LCA) would provide a good estimate of the total net energy and is further discussed in the later sections.

\section{Applications in the field of nutrient recycling}

Thermochemical technologies possess the dual advantage of recovering not only energy, but also valuable nutrients such as $\mathrm{N}$ and $\mathrm{P}$ from organic feedstocks with high nutrient concentration (such as wastewater sludge). While the direct application of the sludge to soil also contributes to nutrient recycling, the leaching and release of nutrients to the soil is often uncontrolled thus leading to some detrimental effects if not spread properly [90]. Additionally, with the presence of rules regarding land application of biosolids and the potential soil contamination and bioaccumulation of antibiotics, pathogens and endocrine disruptors, the land application route is no longer preferred or feasible in many regions $[6,91]$. Technologies such as pyrolysis can preserve a large fraction of the input $\mathrm{N}$ and $\mathrm{P}$ amounts into the solid biochar produced [92]. The biochar has proven to be a useful soil amendment through multiple studies by enabling a controlled release of nutrients while providing additional benefits, such as improved water retention capacity, fertilizer efficiency and crop yield, subject to soil type, crop type and application rate among others [93-95]. The aqueous phase of the hydrothermal technologies on the other hand is the stream where these nutrients are present [96]. There have been multiple efforts at optimizing the recovery of these nutrients by utilizing technologies, including anaerobic digesters, struvite precipitation reactors and different types of membrane reactors, among others. However, the relatively low concentration of the nutrients within this stream makes many of these methods currently infeasible in terms of either energy or economics and further investigations are required to improve the recovery efficiency [97-101].

\section{Effect on heavy metals in the wastewater sludge}

There have been numerous studies dedicated to investigating the concentration of heavy metals in the various solid and liquid streams produced from the wastewater sludge after thermochemical treatment [78, 102]. If the heavy metals can be immobilized within the solid char, and their concentration can be kept below required limits in the oil and gas phases, then this could prove to be another big advantage that the thermochemical technologies would possess over some of the conventional methods. For pyrolysis, specific studies were performed to evaluate the leachability of heavy metals in the biochar and the effects of operating conditions. Similar experiments were performed for hydrothermal technologies, though the results were not as uniform as for the pyrolysis studies. For HTL, owing to the lower operating temperatures as compared to gasification, most of the heavy metals are either present in the solid or liquid phase. Hence, most studies worked on determining the distribution among the two phases and the effects of changing parameters, such as operating temperature, solvent type and catalyst type [9]. Leng et al. [102] investigated the distribution of heavy metals $(\mathrm{Pb}, \mathrm{Zn}, \mathrm{Cu}$ and $\mathrm{Ni})$ in bio-oils and bio-chars obtained from the liquefaction of sewage sludge in different solvents (acetone and ethanol). As for the different liquefaction solvents, there was no obvious difference. Huang et al. [103] too found that the type of liquefaction solvents did not have much influence on the redistribution of heavy metals during the liquefaction process. Yuan et al. [104] found through quantitative risk assessment that zinc $(\mathrm{Zn})$ and cadmium $(\mathrm{Cd})$ were present at hazardous levels in liquefied oils as well as at a lower concentration in fast pyrolysis oils. Huang et al. [105] on the other hand found that the leachability of heavy metals 
was largely suppressed by liquefaction processes and thus we can see some contrasting results here. A few experiments looked at the fate of heavy metals in supercritical and subcritical water technologies too. Shi et al. [106] observed that for the subcritical technologies, most of the heavy metals migrated towards the solid phase but their bioavailability and leachable toxicity was much lesser after treatment (at $280^{\circ} \mathrm{C}$ ) than before. Li et al. [107] analyzed the solid residues from SCWG using a more quantitative approach, and they also found that the bioavailability and toxicity of the heavy metals was reduced, though further attention was requested on elements, such as cadmium $(\mathrm{Cd})$ and zinc $(\mathrm{Zn})$, which still posed certain risks to the environment. Thus, through most studies reviewed, the general consensus was that the thermochemical technologies are capable of reducing the release of heavy metals into the environment and the phase in which heavy metals are concentrated can be controlled.

\section{Life cycle assessment of thermochemical technologies for treating wastewater sludge}

LCA is a systematic tool to quantify the environmental impacts associated with a product, service or process from a cradle-to-grave perspective [108]. Thus, while investigating the environmental impacts of the design and operations of a WWTP, especially its organic wasterelated energy systems, methods such as LCA could prove to be extremely useful [109]. However, most studies that have been conducted so far focus on the entire WWTP operations with little attention to the sludge treatment and ultimate disposal stages [110]. Even within studies on wastewater sludge disposal methods, the focus so far has largely been on conventional methods such as incineration, landfilling, composting and direct land application [111]. Both $\mathrm{Xu}$ et al. [112] and Suh et al. [111] found that the AD of sludge outperformed the landfilling and incineration methods through a comparative LCA. Cao et al. [113] also performed an LCA involving combinations of fast pyrolysis and ADs. The quantitative results have not been provided here as each study had different assumptions and system boundaries as well as different metrics to evaluate the systems. Additionally, most studies noted in their conclusion that there is currently too much uncertainty and variability in the data to correctly quantify the environmental impacts of these technologies, and thus many more such studies are required to improve our understanding of these processes, especially taking into account local factors and conditions $[112,113]$. These results are consistent with the LCA conducted for different feeds such as poultry litter and swine manure where the thermochemical technologies have proven to traditional land application in terms of environmental performance [114]. With further analysis, methodologies such as LCA could help in providing quantitative estimates regarding the extent of improvement in environmental performance of these technologies over the conventional methods.

\section{Techno-economic viability of thermochemical technologies for wastewater sludge treatment}

There have been very few studies looking at the technoeconomic analysis of thermochemical technologies, particularly for the processing and treatment of wastewater sludge [115-117]. Most work has been concentrated on the economics of the upstream processes of a WWTP. Certain studies that looked at the fast pyrolysis and hydrothermal liquefaction of sewage sludge found the respective processes to be economically feasible, subject to policy as well as product and utilities pricing. Kim et al. [116] determined that the bio-oil produced from the fast pyrolysis of sewage sludge could have a value of nearly $\$ 0.1 / \mathrm{kg}$. Lumley et al. [118] investigated the gasification of wastewater sludge and predicted a benefit of as much as $\$ 3.5$ million as compared to landfilling. Studies presenting the techno-economic results for similar thermochemical systems, but with slightly different feedstocks could also provide a reasonable estimate of the performance of these technologies when applied to wastewater sludge [119-122]. Zhu et al. [119] portrayed that a minimum price of $\$ 2.52 /$ gal gasoline-equivalent (GGE) could make the hydrothermal liquefaction of woody biomass feasible when the technology matures. In multiple studies involving the techno-economic analysis and spatial optimization of thermochemical technologies for poultry litter treatment, it was found that these technologies could easily achieve a positive net present value (NPV) with a value of over $\$ 100$ million for large centralized plants processing more than 20 tons/hour [123, 124]. Swanson et al. evaluated the gasification of biomass to produce biofuels and found that an $n^{\text {th }}$ plant could provide a product value in the range of $\$ 4.3 / \mathrm{GGE}$ to $\$ 4.8 /$ GGE [121]. As mentioned earlier, sludge management and treatment is a capital-intensive process that accounts for up to $50 \%$ of the total cost of wastewater treatment $[18,19]$. Thus, it is necessary to analyze the techno-economic feasibility of thermochemical technologies for treating wastewater sludge in the long run with their potential applications in concepts such as circular economy and waste-to-energy.

The concept of the circular economy is considerably different from the traditionally followed linear economic model, and stresses on the reutilization or shifting of end-of-life products (wastes) into inputs for other processes. It also encourages the sustainable utilization of natural resources within systems $[125,126]$. In the context of circular economy, thermochemical technologies, when applied to organic wastes, serve as an excellent 
demonstration of closing the loop. Recycling of materials is incorporated and the levels of waste generation are brought down substantially. The recycling of nutrients also plays a key role in this transition [127]. Furthermore, the intermediate and final products through these processes have shown to possess a large potential in terms of monetary value [121]. For instance, having biochar valued at anywhere between $\$ 20 /$ ton to $\$ 2000 /$ ton demonstrates just how much scope these technologies have if implemented widely and with some supporting policies $[128,129]$. A lot of this value of the biochar is based on the predicted soil benefits through its application and its potential for long-term carbon sequestration [130]. There are many factors that go into this value. Although all of them have not been extensively proven or agreed upon, even having a carbon price as low as $\$ 20$ / ton $\mathrm{CO}_{2}$-eq would make a substantial difference in the economic feasibility of the pyrolysis systems.

With fossil fuels on the decline and oil prices frequently fluctuating based on various technical, political and geographical factors, bio-oils through fast pyrolysis and HTL could provide some of the much-needed stability in certain regions, though the currently expected bio-oil production is much less in magnitude than conventional crude oil. As reviewed in the preceding section, the composition and energy content of the bio-oils produced is variable and strongly dependent on the composition of the feedstock, type of thermochemical conversion process and the chosen reactor type and operating conditions. It is currently clear that most bio-oils produced from these technologies (with the exception of certain cases of catalyzed fast pyrolysis) need to undergo further treatment and downstream processing before they can be used as conventional fuel substitutes, and these methods are considerably expensive to invest in, especially at a small scale $[119,120]$. However, an alternative to this would be the transportation and subsequent upgrading of these bio-oils in a conventional petroleum refinery. As certain studies suggest, it would save a lot of capital investment and be economically feasible if the price of the bio-oil sold is comparable to crude petroleum prices [131].

\section{Conclusions}

There have been a number of significant studies investigating the thermochemical treatment of wastewater sludge with different focuses on various parts of the processes. It is important to be able to compare the products of the technologies in an unbiased manner as that is what would eventually dictate a particular technology's performance. However, only looking at the product distribution is not sufficient as most of the products require some sort of downstream processing before they can be utilized. This is something that is often overlooked and hence an effort was made to incorporate those details along with the applications of these technologies in the fields of waste-to-energy, nutrient recycling and circular economy. Additionally, the fate of certain compounds (originally present in the sludge) during utilization of the products is also necessary to analyze, especially when we are dealing with a feed, such as wastewater sludge, which could have varying concentrations of heavy metals, harmful chemicals, pathogens and antibiotics. Based on the studies performed so far, it seems that the environmental impacts of these compounds are diminished or can be controlled through the thermochemical processes, and that is an important factor to consider for decision makers. The widespread adoption and implementation of these technologies ultimately depends on how their environmental and economic performance compared with the conventional methods, as well as policy changes, such as the restriction on emitting pollutants, higher carbon prices and other green taxes in the future.

\section{Abbreviations \\ AD: Anaerobic digester; daf: Dry ash free basis; db: Dry basis; \\ EPA: Environmental Protection Agency; ER: Equivalence ratio; FT: Fischer- Tropsch; GGE: Gallon gasoline-equivalent; GHG: Greenhouse gas; HHV: Higher heating value; HTL: Hydrothermal liquefaction; LCA: Life cycle assessment; N: Nitrogen; NPV: Net present value; NREL: National Renewable Energy Laboratory; P: Phosphorus; PAH: Polycyclic aromatic hydrocarbons; \\ SCWG: Supercritical water gasification; SCWO: Supercritical water oxidation; UASB: Upflow anaerobic sludge blanket; WWTP: Wastewater treatment plant}

\section{Acknowledgements}

Not applicable.

\section{Authors' contributions}

FY conceived the research. FY, RRB and RER analyzed the results. FY, RRB and RER wrote the manuscript. The authors read and approved the final manuscript.

\section{Funding}

This work is financially supported in part by Cornell University's David R. Atkinson Center for a Sustainable Future for design of the study and collection, analysis, and interpretation of data and in writing the manuscript.

Availability of data and materials

All the raw data of this review paper are publicly available from the cited references. This is a review paper and does not contain original data.

\section{Competing interests}

The authors declare that they have no competing interests.

\section{Author details}

'Robert Frederick Smith School of Chemical and Biomolecular Engineering, Cornell University, Ithaca, NY 14853, USA. ${ }^{2}$ School of Civil and Environmental Engineering, Cornell University, Ithaca, NY 14853, USA. ${ }^{3}$ Atkinson Center for a Sustainable Future, Cornell University, Ithaca, NY 14853, USA.

Received: 27 April 2020 Accepted: 10 June 2020

Published online: 15 June 2020

\section{References}

1. Peccia J, Westerhoff P. We should expect more out of our sewage sludge. Environ Sci Technol. 2015;49(14):8271-6. https://doi.org/10.1021/acs.est. 5b01931.

2. Syed-Hassan SSA, Wang Y, Hu S, Su S, Xiang J. Thermochemical processing of sewage sludge to energy and fuel: fundamentals, challenges and 
considerations. Renew Sustain Energy Rev. 2017;80:888-913. https://doi.org/ 10.1016/.j.rser.2017.05.262

3. Tyagi VK, Lo SL. Sludge: a waste or renewable source for energy and resources recovery? Renew Sustain Energy Rev. 2013;25:708-28. https://doi. org/10.1016/j.rser.2013.05.029

4. Gu Y, Li Y, Li X, Luo P, Wang H, Robinson ZP, et al. The feasibility and challenges of energy self-sufficient wastewater treatment plants. Appl Energy. 2017;204:1463-75. https://doi.org/10.1016/j.apenergy.2017.02.069.

5. Aymerich I, Rieger L, Sobhani R, Rosso D, Corominas L. The difference between energy consumption and energy cost: modelling energy tariff structures for water resource recovery facilities. Water Res. 2015;81:113-23. https://doi.org/10.1016/j.watres.2015.04.033.

6. Clarke BO, Smith SR. Review of 'emerging' organic contaminants in biosolids and assessment of international research priorities for the agricultural use of biosolids. Environ Int. 2011;37(1):226-47. https://doi.org/10.1016/j.envint. 2010.06.004

7. Jones-Lepp TL, Stevens R. Pharmaceuticals and personal care products in biosolids/sewage sludge: the interface between analytical chemistry and regulation. Anal Bioanal Chem. 2007;387(4):1173-83. https://doi.org/10.1007/ s00216-006-0942-z.

8. Lapworth DJ, Baran N, Stuart ME, Ward RS. Emerging organic contaminants in groundwater: a review of sources, fate and occurrence. Environ Pollut. 2012;163:287-303. https://doi.org/10.1016/j.envpol.2011.12.034.

9. Udayanga WDC, Veksha A, Giannis A, Lisak G, Chang WWC, Lim TT. Fate and distribution of heavy metals during thermal processing of sewage sludge. Fuel. 2018;226:721-44. https://doi.org/10.1016/j.fuel.2018.04.045.

10. Lewis DL, Gattie DK. Pathogen risks from applying sewage sludge to land. Environ Sci Technol. 2002;36(13):286A-93A. https://doi.org/10.1021/ es0223426.

11. Fytili D, Zabaniotou A. Utilization of sewage sludge in EU application of old and new methods - a review. Renew Sustain Energy Rev. 2008;12(1):116-40. https://doi.org/10.1016/j.rser.2006.05.014.

12. Chen QY, Tyrer M, Hills CD, Yang XM, Carey P. Immobilisation of heavy metal in cement-based solidification/stabilisation: a review. Waste Manag. 2009;29(1):390-403. https://doi.org/10.1016/j.wasman.2008.01.019.

13. Rodriguez NH, Martinez-Ramirez S, Blanco-Varela MT, Donatello S, Guillem M, Puig J, et al. The effect of using thermally dried sewage sludge as an alternative fuel on Portland cement clinker production. J Clean Prod. 2013; 52:94-102. https://doi.org/10.1016/j.jclepro.2013.02.026.

14. Valls S, Vazquez E. Stabilisation and solidification of sewage sludges with Portland cement. Cem Concr Res. 2000;30(10):1671-8. https://doi.org/10. 1016/s0008-8846(00)00363-x.

15. Furness DT, Hoggett LA, Judd SJ. Thermochemical treatment of sewage sludge. J Chartered Inst Water Environ Manage. 2000;14(1):57-65.

16. Chun YN, Kim SC, Yoshikawa K. Pyrolysis gasification of dried sewage sludge in a combined screw and rotary kiln gasifier. Appl Energy. 2011;88(4):110512. https://doi.org/10.1016/j.apenergy.2010.10.038.

17. Manara P, Zabaniotou A. Towards sewage sludge based biofuels via thermochemical conversion - a review. Renew Sustain Energy Rev. 2012; 16(5):2566-82. https://doi.org/10.1016/j.rser.2012.01.074.

18. Campbell HW. Sludge management - future issues and trends. Water Sc Technol. 2000;41(8):1-8.

19. Rulkens $W$. Sewage sludge as a biomass resource for the production of energy: overview and assessment of the various options. Energy Fuel. 2008; 22(1):9-15. https://doi.org/10.1021/ef700267m.

20. Liu BB, Wei Q, Zhang B, Bi J. Life cycle GHG emissions of sewage sludge treatment and disposal options in tai Lake watershed, China. Sci Total Environ. 2013;447:361-9. https://doi.org/10.1016/j.scitotenv.2013.01.019.

21. Oladejo J, Shi KQ, Luo X, Yang G, Wu T. A review of sludge-to-energy recovery methods. Energies. 2019;12(1). https://doi.org/10.3390/en12010060.

22. Zhang $\mathrm{LH}, \mathrm{Xu} \mathrm{CB}$, Champagne P. Overview of recent advances in thermochemical conversion of biomass. Energ Conver Manage. 2010;51(5):969-82. https://doi.org/10.1016/j.enconman.2009.11.038.

23. Skaggs RL, Coleman AM, Seiple TE, Milbrandt AR. Waste-to-energy biofuel production potential for selected feedstocks in the conterminous United States. Renew Sustain Energy Rev. 2018;82:2640-51. https://doi.org/10.1016/ j.rser.2017.09.107.

24. Snowden-Swan L, Zhu Y, Jones SB, Elliott DC, Schmidt AJ, Hallen RT, et al. Hydrothermal liquefaction and upgrading of municipal wastewater treatment plant sludge: a preliminary techno-economic analysisPNNL-25464-Rev.1; Other:
BM0102060 United States 10.2172/1327165 Other: BM0102060 PNNL English. Richland: Pacific Northwest National Lab. (PNNL); 2016.

25. Q\&A fact sheet - Land application and composting of biosolids; WEF (Water Environment Federation) 2010.

26. Clarke RM, Cummins E. Evaluation of "classic" and emerging contaminants resulting from the application of biosolids to agricultural lands: a review. Hum Ecol Risk Assess. 2015;21 (2):492-513. https://doi.org/10.1080/10807039. 2014.930295.

27. Pruden A, Pei R, Storteboom H, Carlson KH. Antibiotic resistance genes as emerging contaminants: studies in northern Colorado. Environ Sci Technol. 2006;40(23):7445-50. https://doi.org/10.1021/es0604131.

28. A plain english guide to the EPA Part 503 Biosolids Rule U.S. Environmental Protection Agency (U.S. EPA): Washington, DC, 1994.

29. Lu Q, He ZL, Stoffella PJ. Land application of biosolids in the USA: a review. Appl Environ Soil Sci. 2012. https://doi.org/10.1155/2012/201462.

30. Roy MM, Dutta A, Corscadden K, Havard P, Dickie L. Review of biosolids management options and co-incineration of a biosolid-derived fuel. Waste Manag. 2011;31(11):2228-35. https://doi.org/10.1016/j.wasman.2011.06.008.

31. Zhang LH, Xu CB, Champagne P, Mabee W. Overview of current biological and thermo-chemical treatment technologies for sustainable sludge management. Waste Manag Res. 2014;32(7):586-600. https://doi.org/10. 1177/0734242×14538303

32. Aracil C, Haro P, Fuentes-Cano D, Gomez-Barea A. Implementation of wasteto-energy options in landfill-dominated countries: economic evaluation and GHG impact. Waste Manag. 2018;76:443-56. https://doi.org/10.1016/j. wasman.2018.03.039.

33. Fonts I, Gea G, Azuara M, Abrego J, Arauzo J. Sewage sludge pyrolysis for liquid production: a review. Renew Sustain Energy Rev. 2012;16(5):2781-805. https://doi.org/10.1016/j.rser.2012.02.070.

34. Adar E, Karatop B, Ince M, Bilgili MS. Comparison of methods for sustainable energy management with sewage sludge in Turkey based on SWOT-FAHP analysis. Renew Sustain Energy Rev. 2016;62:429-40. https://doi.org/10.1016/ j.rser.2016.05.007.

35. Posmanik R, Labatut RA, Kim AH, Usack JG, Tester JW, Angenent LT. Coupling hydrothermal liquefaction and anaerobic digestion for energy valorization from model biomass feedstocks. Bioresour Technol. 2017;233: 134-43. https://doi.org/10.1016/j.biortech.2017.02.095.

36. Marrone PA. Genifuel hydrothermal processing bench-scale technology evaluation project. Alexandria: Water Environment and Reuse Foundation; 2016.

37. Salman CA, Schwede S, Thorin E, Li HL, Yan JY. Identification of thermochemical pathways for the energy and nutrient recovery from digested sludge in wastewater treatment plants. In: Yan J, Yang HX, Li H, Chen X, editors. Innovative solutions for energy transitions, vol. 158; 2019. p. 1317-22.

38. Bianchini A, Bonfiglioli L, Pellegrini M, Saccani C. Sewage sludge drying process integration with a waste-to-energy power plant. Waste Manag. 2015;42:159-65. https://doi.org/10.1016/j.wasman.2015.04.020.

39. Trinh TN, Jensen PA, Dam-Johansen K, Knudsen NO, Sorensen HR. Influence of the pyrolysis temperature on sewage sludge product distribution, bio-oil, and char properties. Energy Fuel. 2013;27(3):1419-27. https://doi.org/10. 1021/ef301944r.

40. Fonts I, Juan A, Gea G, Murillo MB, Sanchez JL. Sewage sludge pyrolysis in fluidized bed, 1: influence of operational conditions on the product distribution. Ind Eng Chem Res. 2008;47(15):5376-85. https://doi.org/10. 1021/ie7017788.

41. Shen L, Zhang DK. An experimental study of oil recovery from sewage sludge by low-temperature pyrolysis in a fluidised-bed. Fuel. 2003:82(4):46572. https://doi.org/10.1016/s0016-2361(02)00294-6.

42. Alvarez J, Lopez G, Amutio M, Artetxe M, Barbarias I, Arregi A, et al. Characterization of the bio-oil obtained by fast pyrolysis of sewage sludge in a conical spouted bed reactor. Fuel Process Technol. 2016;149:169-75. https://doi.org/10.1016/j.fuproc.2016.04.015.

43. Chen SY, Sun Z, Zhang Q, Hu J, Xiang WG. Steam gasification of sewage sludge with $\mathrm{CaO}$ as $\mathrm{CO} 2$ sorbent for hydrogen-rich syngas production. Biomass Bioenergy. 2017;107:52-62. https://doi.org/10.1016/j.biombioe.2017. 09.009 .

44. Chen YA, Guo LJ, Cao W, Jin H, Guo SM, Zhang XM. Hydrogen production by sewage sludge gasification in supercritical water with a fluidized bed reactor. Int J Hydrogen Energy. 2013;38(29):12991-9. https://doi.org/10.1016/ j.ijhydene.2013.03.165 
45. Freda C, Cornacchia G, Romanelli A, Valerio V, Grieco M. Sewage sludge gasification in a bench scale rotary kiln. Fuel. 2018;212:88-94. https://doi. org/10.1016/j.fuel.2017.10.013.

46. Lee U, Dong J, Chung JN. Experimental investigation of sewage sludge solid waste conversion to syngas using high temperature steam gasification. Energ Conver Manage. 2018;158:430-6. https://doi.org/10.1016/j.enconman. 2017.12.081

47. Fonts I, Azuara M, Gea G, Murillo MB. Study of the pyrolysis liquids obtained from different sewage sludge. J Anal Appl Pyrolysis. 2009;85(1-2):184-91. https://doi.org/10.1016/j.jaap.2008.11.003.

48. Huang YF, Shih CH, Chiueh PT, Lo SL. Microwave co-pyrolysis of sewage sludge and rice straw. Energy. 2015;87:638-44. https://doi.org/10.1016/j. energy.2015.05.039.

49. Xie QL, Peng P, Liu SY, Min M, Cheng YL, Wan YQ, et al. Fast microwaveassisted catalytic pyrolysis of sewage sludge for bio-oil production. Bioresour Technol. 2014;172:162-8. https://doi.org/10.1016/j.biortech.2014. 09.006.

50. Zhou JW, Liu SY, Zhou N, Fan LL, Zhang YN, Peng P, et al. Development and application of a continuous fast microwave pyrolysis system for sewage sludge utilization. Bioresour Technol. 2018;256:295-301. https://doi.org/10. 1016/j.biortech.2018.02.034

51. Calvo LF, Garcia Al, Otero M. An experimental investigation of sewage sludge gasification in a fluidized bed reactor. Sci World J. 2013. https://doi. org/10.1155/2013/479403.

52. Qian LL, Wang SZ, Xu DH, Guo Y, Tang XY, Wang LF. Treatment of sewage sludge in supercritical water and evaluation of the combined process of supercritical water gasification and oxidation. Bioresour Technol. 2015;176: 218-24. https://doi.org/10.1016/j.biortech.2014.10.125.

53. Pedroza MM, Sousa JF, Vieira GEG, Bezerra MBD. Characterization of the products from the pyrolysis of sewage sludge in $1 \mathrm{~kg} / \mathrm{h}$ rotating cylinder reactor. J Anal Appl Pyrolysis. 2014;105:108-15. https://doi.org/10.1016/j.jaap. 2013.10.009.

54. Xu DH, Lin GK, Liu L, Wang Y, Jing ZF, Wang SZ. Comprehensive evaluation on product characteristics of fast hydrothermal liquefaction of sewage sludge at different temperatures. Energy. 2018;159:686-95. https://doi.org/ 10.1016/j.energy.2018.06.191.

55. Demirbas A. Biomass resource facilities and biomass conversion processing for fuels and chemicals. Energ Conver Manage. 2001;42(11):1357-78. https:// doi.org/10.1016/s0196-8904(00)00137-0.

56. Balat M, Balat M, Kirtay E, Balat H. Main routes for the thermo-conversion of biomass into fuels and chemicals. Part 1: pyrolysis systems. Energ Conver Manage. 2009;50(12):3147-57. https://doi.org/10.1016/j.enconman.2009.08.014.

57. Zhang Q, Gong J, Skwarczek M, Yue D, You F. Sustainable process design and synthesis of hydrocarbon biorefinery through fast pyrolysis and

Hydroprocessing. AICHE J. 2014;60(3):980-94. https://doi.org/10.1002/aic.14344.

58. Bruun EW, Ambus P, Egsgaard H, Hauggaard-Nielsen $H$. Effects of slow and fast pyrolysis biochar on soil $\mathrm{C}$ and $\mathrm{N}$ turnover dynamics. Soil Biol Biochem. 2012;46:73-9. https://doi.org/10.1016/j.soilbio.2011.11.019

59. Fonts I, Juan A, Gea G, Murillo MB, Arauzo J. Sewage sludge pyrolysis in a fluidized bed, 2: influence of operating conditions on some physicochemical properties of the liquid product. Ind Eng Chem Res. 2009; 48(4):2179-87. https://doi.org/10.1021/ie801448g.

60. Park HJ, Heo HS, Park YK, Yim JH, Jeon JK, Park J, et al. Clean bio-oi production from fast pyrolysis of sewage sludge: effects of reaction conditions and metal oxide catalysts. Bioresour Technol. 2010;101:S83-5. https://doi.org/10.1016/j.biortech.2009.06.103.

61. Leng LJ, Li H, Yuan XZ, Zhou WG, Huang HJ. Bio-oil upgrading by emulsification/microemulsification: a review. Energy. 2018;161:214-32. https://doi.org/10.1016/j.energy.2018.07.117.

62. Chiaramonti D, Oasmaa A, Solantausta Y. Power generation using fast pyrolysis liquids from biomass. Renew Sustain Energy Rev. 2007;11(6):105686. https://doi.org/10.1016/j.rser.2005.07.008.

63. Balat M, Balat M, Kirtay E, Balat H. Main routes for the thermo-conversion of biomass into fuels and chemicals. Part 2: gasification systems. Energ Conver Manage. 2009;50(12):3158-68. https://doi.org/10.1016/j.enconman.2009.08.013.

64. Demirbas A. Gaseous products from biomass by pyrolysis and gasification: effects of catalyst on hydrogen yield. Energ Conver Manage. 2002;43(7):897909. https://doi.org/10.1016/s0196-8904(01)00080-2.

65. Hernandez JJ, Aranda-Almansa G, Bula A. Gasification of biomass wastes in an entrained flow gasifier: effect of the particle size and the residence time.
Fuel Process Technol. 2010;91(6):681-92. https://doi.org/10.1016/j.fuproc. 2010.01.018.

66. Lv PM, Xiong ZH, Chang J, Wu CZ, Chen Y, Zhu JX. An experimental study on biomass air-steam gasification in a fluidized bed. Bioresour Technol. 2004;95(1):95-101. https://doi.org/10.1016/j.biortech.2004.02.003.

67. Demirbas A. Biomass gasification for power generation in Turkey. Energy Sources Part a-Recovery Utilization Environ Effects. 2006;28(5):433-45. https://doi.org/10.1080/009083190913584.

68. Demirbas A. Converting biomass derived synthetic gas to fuels via fishertropsch synthesis. Energy Sources Part a-Recovery Utilization Environ Effects. 2007;29(16):1507-12. https://doi.org/10.1080/15567030601003676.

69. Wang B, Gebreslassie BH, You F. Sustainable design and synthesis of hydrocarbon biorefinery via gasification pathway: integrated life cycle assessment and technoeconomic analysis with multiobjective superstructure optimization. Comput Chem Eng. 2013;52:55-76. https://doi. org/10.1016/j.compchemeng.2012.12.008.

70. Dutta A, Phillips SD. Thermochemical ethanol via direct gasification and mixed alcohol synthesis of lignocellulosic biomassNREL/TP-510-45913; TRN: US200915\%\%391 United States 10.2172/962020 TRN: US200915\%\%391 NREL English. Golden: National Renewable Energy Lab. (NREL); 2009.

71. Phillips S, Aden A, Jechura J, Dayton D, Eggeman T. Thermochemical ethanol via indirect gasification and mixed alcohol synthesis of lignocellulosic biomassNREL/TP-510-41168; TRN: US200719\%\%596 United States 10.2172/902168 TRN: US200719\%\%596 NREL English. Golden: National Renewable Energy Lab. (NREL); 2007.

72. Worley M, Yale J. Biomass gasification technology assessment: consolidated reportNREL/SR-5100-57085; Other: LFA-2-22480-01 United States 10.2172/ 1059145 Other: LFA-2-22480-01 NREL English. Golden: National Renewable Energy Lab. (NREL); 2012.

73. Hu M, Gao L, Chen ZH, Ma CF, Zhou Y, Chen J, et al. Syngas production by catalytic in-situ steam co-gasification of wet sewage sludge and pine sawdust. Energ Conver Manage. 2016;111:409-16. https://doi.org/10.1016/j. enconman.2015.12.064.

74. Li HH, Chen ZH, Huo C, Hu M, Guo DB, Xiao B. Effect of bioleaching on hydrogen-rich gas production by steam gasification of sewage sludge. Energ Conver Manage. 2015;106:1212-8. https://doi.org/10.1016/j. enconman.2015.10.048.

75. Choi YK, Ko JH, Kim JS. Gasification of dried sewage sludge using an innovative three-stage gasifier: clean and $\mathrm{H}$-2-rich gas production using condensers as the only secondary tar removal apparatus. Fuel. 2018;216: 810-7. https://doi.org/10.1016/j.fuel.2017.12.068.

76. Devi L, Ptasinski KJ, Janssen F. A review of the primary measures for tar elimination in biomass gasification processes. Biomass Bioenergy. 2003;24(2): 125-40. https://doi.org/10.1016/s0961-9534(02)00102-2.

77. Peterson AA, Vogel F, Lachance RP, Fröling M, Antal JMJ, Tester JW. Thermochemical biofuel production in hydrothermal media: a review of sub- and supercritical water technologies. Energ Environ Sci. 2008;1:32-65. https://doi.org/10.1039/b810100k.

78. Mulchandani A, Westerhoff P. Recovery opportunities for metals and energy from sewage sludges. Bioresour Technol. 2016;215:215-26. https://doi.org/ 10.1016/j.biortech.2016.03.075.

79. Chen W-T, Zhang Y, Zhang J, Yu G, Schideman LC, Zhang P, et al. Hydrothermal liquefaction of mixed-culture algal biomass from wastewater treatment system into bio-crude oil. Bioresour Technol. 2014;152:130-9. https://doi.org/10.1016/j.biortech.2013.10.111.

80. Reddy SN, Nanda S, Dalai AK, Kozinski JA. Supercritical water gasification of biomass for hydrogen production. Int J Hydrogen Energy. 2014;39(13):691226. https://doi.org/10.1016/j.ijhydene.2014.02.125.

81. Yakaboylu O, Harinck J, Smit KG, de Jong W. Supercritical water gasification of biomass: a literature and technology overview. Energies. 2015;8(2):85994. https://doi.org/10.3390/en8020859.

82. Garcia DJ, You F. Systems engineering opportunities for agricultural and organic waste management in the food-water-energy nexus. Curr Opin Chem Eng. 2017;18:23-31. https://doi.org/10.1016/j.coche.2017.08.004.

83. Garcia DJ, You F. The water-energy-food nexus and process systems engineering: a new focus. Comput Chem Eng. 2016;91:49-67. https://doi. org/10.1016/j.compchemeng.2016.03.003.

84. Yue D, You F, Snyder SW. Biomass-to-bioenergy and biofuel supply chain optimization: overview, key issues and challenges. Comput Chem Eng. 2014; 66:36-56. https://doi.org/10.1016/j.compchemeng.2013.11.016. 
85. Egan M. Biosolids management strategies: an evaluation of energy production as an alternative to land application. Environ Sci Pollut Res. 2013;20(7):4299-310.

86. Wright MM, Satrio JA, Brown RC, Daugaard DE, Hsu DD. Techno-economic analysis of biomass fast pyrolysis to transportation fuels. Golden: NREL/TP6A20-46586; National Renewable Energy Lab. (NREL); 2010.

87. Gebreslassie BH, Slivinsky M, Wang B, You F. Life cycle optimization for sustainable design and operations of hydrocarbon biorefinery via fast pyrolysis, hydrotreating and hydrocracking. Comput Chem Eng. 2013;50:7191. https://doi.org/10.1016/j.compchemeng.2012.10.013.

88. McCarty PL, Bae J, Kim J. Domestic wastewater treatment as a net energy producer-can this be achieved? Environ Sci Technol. 2011;45(17):7100-6. https://doi.org/10.1021/es2014264.

89. Nicoletti J, Ning C, You F. Incorporating agricultural waste-to-energy pathways into biomass product and process network through data-driven nonlinear adaptive robust optimization. Energy. 2019;180:556-71. https://doi. org/10.1016/j.energy.2019.05.096.

90. Zhang QG, Hu JJ, Lee DJ, Chang YJ, Lee YJ. Sludge treatment: current research trends. Bioresour Technol. 2017;243:1159-72. https://doi.org/10. 1016/j.biortech.2017.07.070

91. Bondarczuk K, Markowicz A, Piotrowska-Seget Z. The urgent need for risk assessment on the antibiotic resistance spread via sewage sludge land application. Environ Int. 2016;87:49-55. https://doi.org/10.1016/j.envint.2015. 11.011.

92. Angst TE, Sohi SP. Establishing release dynamics for plant nutrients from biochar. GCB Bioenergy. 2013;5(2):221-6. https://doi.org/10.1111/gcbb. 12023.

93. Mohammadi A, Cowie AL, Cacho O, Kristiansen P, Mai TLA, Joseph S. Biochar addition in rice farming systems: economic and energy benefits. Energy. 2017;140:415-25. https://doi.org/10.1016/j.energy.2017.08.116.

94. Jeffery S, Abalos D, Prodana M, Bastos AC, van Groenigen JW, Hungate BA, et al. Biochar boosts tropical but not temperate crop yields. Environ Res Lett. 2017;12(5). https://doi.org/10.1088/1748-9326/aa67bd.

95. Jeffery $\mathrm{S}$, Verheijen FGA, van der Velde M, Bastos AC. A quantitative review of the effects of biochar application to soils on crop productivity using meta-analysis. Agric Ecosyst Environ. 2011;144(1):175-87. https://doi.org/10. 1016/j.agee.2011.08.015.

96. Van Doren LG, Posmanik R, Bicalho FA, Tester JW, Sills DL. Prospects for energy recovery during hydrothermal and biological processing of waste biomass. Bioresour Technol. 2017;225:67-74. https://doi.org/10.1016/j. biortech.2016.11.030

97. Bloecher C, Niewersch C, Melin T. Phosphorus recovery from sewage sludge with a hybrid process of low pressure wet oxidation and nanofiltration. Water Res. 2012;46(6):2009-19. https://doi.org/10.1016/j.watres.2012.01.022.

98. de Bashan LE, Bashan Y. Recent advances in removing phosphorus from wastewater and its future use as fertilizer (1997-2003). Water Res. 2004; 38(19):4222-46. https://doi.org/10.1016/j.watres.2004.07.014

99. Kumar $R, P a l P$. Assessing the feasibility of $N$ and $P$ recovery by struvite precipitation from nutrient-rich wastewater: a review. Environ Sci Pollut Res. 2015;22(22):17453-64.

100. Lesjean B, Gnirss R, Adam C, Kraume M, Luck F. Enhanced biological phosphorus removal process implemented in membrane bioreactors to improve phosphorous recovery and recycling. Water Sci Technol. 2003;48(1): 87-94.

101. Munch EV, Barr K. Controlled struvite crystallisation for removing phosphorus from anaerobic digester sidestreams. Water Res. 2001;35(1):1519. https://doi.org/10.1016/s0043-1354(00)00236-0.

102. Leng $L$, Yuan $X Z$, Huang $H J$, Jiang HW, Chen XH, Zeng GM. The migration and transformation behavior of heavy metals during the liquefaction process of sewage sludge. Bioresour Technol. 2014;167:144-50. https://doi. org/10.1016/j.biortech.2014.05.119.

103. Huang HJ, Yuan XZ. The migration and transformation behaviors of heavy metals during the hydrothermal treatment of sewage sludge. Bioresour Technol. 2016;200:991-8. https://doi.org/10.1016/j.biortech.2015.10.099.

104. Yuan XZ, Leng LJ, Huang HJ, Chen XH, Wang H, Xiao ZH, et al. Speciation and environmental risk assessment of heavy metal in bio-oil from liquefaction/pyrolysis of sewage sludge. Chemosphere. 2015;120:645-52. https://doi.org/10.1016/j.chemosphere.2014.10.010.

105. Huang HJ, Yuan XZ, Zeng GM, Zhu HN, Li H, Liu ZF, et al. Quantitative evaluation of heavy metals' pollution hazards in liquefaction residues of sewage sludge. Bioresour Technol. 2011;102(22):10346-51. https://doi.org/ 10.1016/j.biortech.2011.08.117.

106. Shi WS, Liu CG, Ding DH, Lei ZF, Yang YN, Feng CP, et al. Immobilization of heavy metals in sewage sludge by using subcritical water technology. Bioresour Technol. 2013;137:18-24. https://doi.org/10.1016/j.biortech.2013. 03.106.

107. Li L, Xu ZR, Zhang CL, Bao JP, Dai XX. Quantitative evaluation of heavy metals in solid residues from sub- and super-critical water gasification of sewage sludge. Bioresour Technol. 2012;121:169-75. https://doi.org/10.1016/ j.biortech.2012.06.084.

108. Corominas L, Foley J, Guest JS, Hospido A, Larsen HF, Morera S, et al. Life cycle assessment applied to wastewater treatment: state of the art. Water Res. 2013;47(15):5480-92. https://doi.org/10.1016/j.watres.2013.06.049.

109. Gong J, You F. Sustainable design and synthesis of energy systems. Curr Opin Chem Eng. 2015;10:77-86. https://doi.org/10.1016/j.coche.2015.09.001.

110. Yoshida H, Christensen TH, Scheutz C. Life cycle assessment of sewage sludge management: a review. Waste Manag Res. 2013;31(11):1083-101. https://doi.org/10.1177/0734242×13504446.

111. Suh YJ, Rousseaux P. An LCA of alternative wastewater sludge treatment scenarios. Resources Conserv Recycling. 2002;35(3):191-200. https://doi.org/ 10.1016/s0921-3449(01)00120-3.

112. Xu CQ, Chen W, Hong JL. Life-cycle environmental and economic assessment of sewage sludge treatment in China. J Clean Prod. 2014;67:7987. https://doi.org/10.1016/j.jclepro.2013.12.002.

113. Cao YC, Pawlowski A. Life cycle assessment of two emerging sewage sludge-to-energy systems: evaluating energy and greenhouse gas emissions implications. Bioresour Technol. 2013;127:81-91. https://doi.org/10.1016/j. biortech.2012.09.135.

114. Fernandez-Lopez M, Puig-Gamero M, Lopez-Gonzalez D, Avalos-Ramirez A, Valverde J, Sanchez-Silva L. Life cycle assessment of swine and dairy manure: pyrolysis and combustion processes. Bioresour Technol. 2015;182: 184-92. https://doi.org/10.1016/j.biortech.2015.01.140.

115. Bridgwater AV, Toft AJ, Brammer JG. A techno-economic comparison of power production by biomass fast pyrolysis with gasification and combustion. Renew Sustain Energy Rev. 2002;6(3):181-248. https://doi.org/ 10.1016/s1364-0321(01)00010-7.

116. Kim Y, Parker W. A technical and economic evaluation of the pyrolysis of sewage sludge for the production of bio-oil. Bioresour Technol. 2008;99(5): 1409-16. https://doi.org/10.1016/j.biortech.2007.01.056.

117. Werle S, Sobek S. Gasification of sewage sludge within a circular economy perspective: a polish case study. Environ Sci Pollut Res. 2019;26(35):3542232. https://doi.org/10.1007/s11356-019-05897-2.

118. Lumley NPG, Ramey DF, Prieto AL, Braun RJ, Cath TY, Porter JM. Technoeconomic analysis of wastewater sludge gasification: a decentralized urban perspective. Bioresour Technol. 2014;161:385-94. https://doi.org/10.1016/j. biortech.2014.03.040

119. Zhu YH, Biddy MJ, Jones SB, Elliott DC, Schmidt AJ. Techno-economic analysis of liquid fuel production from woody biomass via hydrothermal liquefaction (HTL) and upgrading. Appl Energy. 2014;129:384-94. https://doi. org/10.1016/j.apenergy.2014.03.053

120. Jones SB, Zhu Y, Anderson DB, Hallen RT, Elliott DC, Schmidt AJ, et al. Process design and economics for the conversion of algal biomass to hydrocarbons: whole algae hydrothermal liquefaction and upgrading. Richland: PNNL-23227; Pacific Northwest National Lab. (PNNL); 2014.

121. Swanson RM, Platon A, Satrio JA, Brown RC, Hsu DD. Techno-economic analysis of biofuels production based on gasification. Golden: NREL/TP6A20-46587; National Renewable Energy Lab. (NREL); 2010.

122. Anex RP, Aden A, Kazi FK, Fortman J, Swanson RM, Wright MM, et al. Techno-economic comparison of biomass-to-transportation fuels via pyrolysis, gasification, and biochemical pathways. Fuel. 2010;89:S29-35. https://doi.org/10.1016/j.fuel.2010.07.015.

123. Bora RR, Lei M, Tester JW, Lehmann J, You F. Life cycle assessment and Technoeconomic analysis of thermochemical conversion technologies applied to poultry litter with energy and nutrient recovery. ACS Sustain Chem Eng. 2020;8(22):8436-47. https://doi.org/10.1021/acssuschemeng. 0c02860.

124. Zhao N, Lehmann J, You F. Poultry waste valorization via pyrolysis technologies: economic and environmental life cycle optimization for sustainable bioenergy systems. ACS Sustain Chem Eng. 2020;8(11):4633-46. https://doi.org/10.1021/acssuschemeng.0c00704. 
125. Gherghel A, Teodosiu C, De Gisi S. A review on wastewater sludge valorisation and its challenges in the context of circular economy. J Clean Prod. 2019;228:244-63. https://doi.org/10.1016/j.jclepro.2019.04.240.

126. Garcia DJ, Lovett BM, You F. Considering agricultural wastes and ecosystem services in food-energy-water-waste nexus system design. J Clean Prod. 2019;228:941-55. https://doi.org/10.1016/j.jclepro.2019.04.314

127. Smol M. The importance of sustainable phosphorus management in the circular economy (CE) model: the polish case study. J Material Cycles Waste Manage. 2019;21(2):227-38. https://doi.org/10.1007/s10163-018-0794-6.

128. Meyer S, Glaser B, Quicker P. Technical, economical, and climate-related aspects of biochar production technologies: a literature review. Environ Sci Technol. 2011;45(22):9473-83. https://doi.org/10.1021/es201792c.

129. Lehmann J, Joseph S. Biochar for environmental management : science, technology and implementation. 2nd ed. London: Routledge; 2015.

130. Roberts KG, Gloy BA, Joseph S, Scott NR, Lehmann J. Life cycle assessment of biochar systems: estimating the energetic, economic, and climate change potential. Environ Sci Technol. 2010;44(2):827-33. https://doi.org/10.1021/ es902266r.

131. Freeman CJ, Jones SB, Padmaperuma AB, Santosa DM, Valkenburg C, Shinn J. Initial assessment of U.S. refineries for purposes of potential bio-based oil insertions. Richland: PNNL-22432; Pacific Northwest National Lab. (PNNL); 2013

\section{Publisher's Note}

Springer Nature remains neutral with regard to jurisdictional claims in published maps and institutional affiliations.

Ready to submit your research? Choose BMC and benefit from:

- fast, convenient online submission

- thorough peer review by experienced researchers in your field

- rapid publication on acceptance

- support for research data, including large and complex data types

- gold Open Access which fosters wider collaboration and increased citations

- maximum visibility for your research: over $100 \mathrm{M}$ website views per year

At $B M C$, research is always in progress.

Learn more biomedcentral.com/submissions 